\title{
Affixes Analysis In A "Hansel And Gretel” Story To English Young Learners: A Morphology Perspective
}

\author{
Paramita Kusumawardhani \\ English Department \\ e-mail: paramita.pmi@bsi.ac.id

\begin{tabular}{ccc}
\hline Diterima & Direvisi & Disetujui \\
$14-01-2020$ & $06-02-2020$ & $25-02-2020$ \\
\hline
\end{tabular}

\begin{abstract}
The aims of this research are to know about kinds of affix and how they are used in a story. Affix is a part of morphology and morphology is the study of the internal structure of word. There are two kinds of morphology, they are derivational and inflectional. Derivational morphology is related to affixes. Affixes can be distinguished by two primary types, they are: prefixes and suffixes. Prefixes are attached at the beginning of a lexical item or base morpheme; meanwhile, suffixes are attached at the end of a lexical item or base morpheme. There are two ways of affixes; (1) according to the positions and (2) according to the functions. According to the positions, there 3 types of affixes, they are prefix, infix and suffix. According to the functions, there 2 types of affixes, they are derivational affixes and inflectional affixes. Derivational affixes cause the semantic change, such as bake - baker, happy - unhappy, like - dislike; and category change, such as run (verb) - runner (noun), dangerous (adjective) - dangerously (adverb), writing (noun) - write (verb). Affixes are common used in a story. The participants of this research are the students at one of English Courses in Gading Serpong, Tangerang. Descriptive qualitative was used as the method to do the research. The results of this research are: there are 2 prefixes found in the story, they are re-and step-, meanwhile there 5 suffixes found in the story, they are -er, -ed, $-s$, -ly and -ing.
\end{abstract}

\section{Keywords: Morphology, Affixation, Hansel and Gretel Story, EYL}

\begin{abstract}
Abstrak - Tujuan dari penelitian ini adalah mengetahui jenis-jenis imbuhan dan bagaimana penggunaan imbuhan dalam suatu cerita. Imbuhan adalah bagian dari morfologi dan morfologi adalah ilmu yang mempelajari tentang susunan kata. Ada dua macam morfologi yaitu derivasi dan infleksi. Morfologi derivasi berhubungan dengan imbuhan. Imbuhan dapat dikenali melalui dua cara, yaitu awalan dan akhiran. Awalan adalah imbuhan yang diletakkan di awal kata dan akhiran adalah imbuhan yang diletakkan di akhir kata. Imbuhan terdiri dari dua macam yaitu berdasarkan letaknya dan berdasarkan fungsinya. Berdasarkan letaknya, imbuhan terdiri dari 3 jenis, yaitu awalan, sisipan dan akhiran. Berdasarkan fungsinya, imbuhan terdiri dari imbuhan derivasi dan infleksi. Imbuhan derivasi yaitu imbuhan yang menyebabkan perubahan arti kata seperti bake - baker, happy - unhappy, like - dislike; dan perubahan bagian kata seperti run (verb) - runner (noun), dangerous (adjective) - dangerously (adverb), writing (noun) - write (verb). Imbuhan sering digunakan dalam suatu cerita. Partisipan dari penelitian ini adalah murid-murid di salah satu tempat kursus bahasa Inggris di Gading Serpong, Tangerang. Metode yang digunakan dalam penelitian ini adalah deskriptif kualitatif. Hasil dari penelitian ini yaitu terdapat 2 awalan yaitu re-dan step-lalu 5 akhiran, yaitu -er, -ed, -s, -ly dan-ing.
\end{abstract}

Kata kunci: Morfologi, Imbuhan, Cerita Hansel dan Gretel, EYL

\section{INTRODUCTION}

There are some kinds in learning English such as; listening, speaking, writing and reading. Writing is the most difficult part in learning English as what we say is different with what we write. Heaton in (Kusumawardhani, 2018), stated, "The writing skills are complex and certainly difficult to teach, requiring not only of grammatical and theoretical devises but also conceptual and judgmental elements".

Some factors made writing in English looks difficult, such as spelling, vocabulary and grammar. There are many aspects in grammar that should be mastered by the learners which can make some errors in learning English. Writing is also concerned about the linguistics because Linguistics discusses about language. In linguistics there are 
branches of the linguistics which one of them has the specific purpose that also help the learners in learning writing. A sign, a visual symbol can be changed through writing. Thus the study of the language will involve the learners in appraisal of all of the following levels of the language, they are: language, phonology which studies about sounds, morphology which studies about meaningful combination of sounds, lexis which studies about words, syntax which studies about meaningful combination of words, semantic which studies about meaning and discourse which studies about how syntax is combined.

There are two kinds of morphology, they are: derivational and inflectional morphology. Derivational morphology discusses about the morphemes can be used to form new words. It also studies the principles governing the construction of new words, without reference to the specific grammatical role a word might play in a sentence. Inflectional morphology occurs with nouns, pronouns and verbs. It also studies about the way in varying the words in order to express grammatical contrasts in sentences such as singular/plural or present/past tense.

\section{The Definition of Morphology}

The term morphology takes its origin from morph which means form, shape, etc and ology which means a study of something. August Schleicher, a German linguist, named morphology as a sub-discipline of linguistics in 1859 for the first time.

(Aronoff \& Fudeman, n.d.) stated that morphology referred to the mental system involved in word formation or to the branch of linguistics that deals with words, their internal structure and how they are formed. Morphology dealt with the structure of words. Knowing, knowingly and unknowingly are kinds of derivational morphology. The base word is "know" and it is added with morphemes -ing, -ly and un-.

According to (March et al., 2014), morphology is the study of investigating forms in language rather than depending on identifying words. Morphology plays an important role in the construction of linguistic units and structures. It is morphology which allows the language to adopt new words from the existing words (derivational morphology) or to change the grammatical aspect of a word according to its use in a specific context (inflectional morphology).

(Khan, Akram, \& Khan, 2016) explained that the study of morphology contains a thorough examination of several bits of language that combine to make a single linguistic unit, known as the 'word'. Linguistically these bits are called morphemes. A morpheme is a minimal unit of meaning or grammatical function. There are two sub-categories of morphemes, namely free and bound morphemes. Free morphemes can stand by themselves in isolation, e.g. boy, cat, dog etc., while bound morphemes are always attached to free morphemes and never occur in isolation, e.g. -ness in madness. The former contains lexical morphemes that have a dictionary meaning (like wall, book, fan, etc.) and functional morphemes that have grammatical functions to fulfill (like $a$, an, the etc.). The latter contains derivational morphemes and inflectional morphemes. The main difference between the two is that derivational morphemes produce new words in language by changing their word class, e.g. teach-teach-er, while inflectional morphemes indicate aspects of grammatical function of a word and never change its grammatical category e.g. boy-boy-s.

\section{The Definition of Affix}

Morphology has many parts, there are morpheme, lexeme, affixes, and etc. morpheme is the smallest units of meaning. An affix is a morpheme which only occurs when attached to some other morpheme or morpheme such as a root or stem or base.

Affixation is a morphological process which supposed to change a root or base word to form a new word. Affixes are classified into two different ways, they are: (1) according to the positions and (2) according to the functions. According to the positions, affixes are divided into three types of affixes; they are prefix, infix and suffix. Prefix is an affix which is attached before a word, infix is an affix which is inserted into a word, and suffix is an affix which is attached after a word. "Affixes can be attached before or after a base", Katamba in (Josiah \& Udoudom, 2012)

According to the functions, affixes are classified into two types, they are: derivational affixes and inflectional affixes, Brinton in (March et al., 2014). Derivational affixes are affixes which are attached to a word then create a new word, change the meaning of the word or part of speech of the word, such as: un + happy = unhappy, dis + like $=$ dislike, develop + ment $=$ development, refuse + al $=$ refusal. Inflectional affixes are affixes which are attached to a word but they do not create a new word, change the meaning or part of speech of the word. They emphasize to the information which has been mentioned, like number, gender, 
tenses, and person. The examples are: pencil $+\mathrm{s}=$ pencils, walk + ed $=$ walked.
Here are some lists of the most common prefixes and suffixes: 


\section{Handout 7:}

\section{Common Affixes and Their Meanings}

\section{Prefixes}

Prefixes are letter groups added before a base word or root. Prefixes generally add to or change the meaning of a word.

\begin{tabular}{|c|c|c|}
\hline Prefix & Meaning & Example \\
\hline Ab- & away from & absent, abnormal \\
\hline Ad- & to, toward & advance, addition \\
\hline After- & later, behind & aftermath, afterward \\
\hline Anti- & against, opposed & antibiotic, antigravity \\
\hline Auto- & self & automobile, autobiography \\
\hline $\mathrm{Be}-$ & make & believe, belittle \\
\hline $\mathrm{Bi}-$ & two & bicycle, biceps \\
\hline Com, con, co- & with, together & commune, concrete \\
\hline Contra- & against & contradict, contrary \\
\hline De- & downward, undo & deflate, defect \\
\hline Deci- & ten & decibels, decimal \\
\hline Dis- & not & dislike, distrust \\
\hline E, ex- & out of, prior to & explain, expense \\
\hline En, em- & in, into, cover & engage, employ \\
\hline Extra- & outside & extravagant, extraterrestrial \\
\hline Im- & not & impose, imply \\
\hline $\ln -$ & into, not & include, incurable \\
\hline Inter- & among & interact, internal \\
\hline Macro- & large & macroeconomics, macrotiotic \\
\hline Magni- & great & magnify, magnificent \\
\hline Mega- & huge & megaphone, megabucks \\
\hline Micro- & small & miscroscope, microbe \\
\hline Mis- & wrongly & mistake, mislead \\
\hline Non- & not & nonsense, nonviolent \\
\hline Over- & above, beyond & overflow, overdue \\
\hline Post- & after & postdate, postmark \\
\hline Pre- & before, prior to & preheat, prehistoric \\
\hline Pro- & in favor of & protest, protect \\
\hline $\operatorname{Re}-$ & again & repeat, revise \\
\hline Sub- & under, beneath & submarine, subject \\
\hline Super- & above, beyond & superior, supernatural \\
\hline Tele- & far & telescope, telephone \\
\hline
\end{tabular}

Figure 1. Common Affixes and Their Meanings 


\begin{tabular}{|l|l|l|}
\hline Unit 8 & $\begin{array}{l}\text { Vocabulary Instruction Component of a Comprehensive } \\
\text { Reading Program }\end{array}$ \\
& $\begin{array}{l}\text { Handout 7 (continued) } \\
\text { Common Affixes and Their Meanings }\end{array}$ \\
\hline Prefix & Meaning & Example \\
\hline Trans- & across & transfer, transit \\
\hline Tri- & three & tricycle, triangle \\
\hline Un- & not & unknown, unjust \\
\hline Ultra- & beyond & ultraviolet, ultrasuede \\
\hline Under- & beneath, below & underneath, underline \\
\hline Uni- & one, single & unicorn, uniform \\
\hline
\end{tabular}

\section{Suffixes}

Suffixes are groups of letters added after a base word or root. The following is a sample of the wide variety.

\begin{tabular}{|c|c|c|c|}
\hline$\overline{\text { Suffix }}$ & Meaning & Example & \\
\hline -ant & one who & assistant & \\
\hline -ar & one who & liar & \\
\hline -arium & place for & aquarium & \\
\hline -ble & inclined to & gullible & \\
\hline -ent & one who & resident & \\
\hline -er & one who & teacher & \\
\hline -er & more & brighter & \\
\hline -ery, ry & products & pottery & $T$ \\
\hline -ess & one who (female) & actress & $\bar{D}$ \\
\hline -est & most & most $^{\star \star \star \star *}$ & 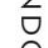 \\
\hline -ful & full of & mouthful & $\stackrel{0}{\subset}$ \\
\hline -ing & material & roofing & ज \\
\hline
\end{tabular}

Figure 2. Common Affixes and Their Meanings 


\section{The Definition of English Young Learners (EYL)}

There is a phenomenon in learning English. Learning English has started in the early age. It has happened since the second half of the century. It is also happened because now English is used in order to face the global demand which emphasis on the need for communication skills.

The process information between EYL and adult is different. Children, start from an early age, begin to sort out words involving concrete subjects. It happens when EYL study about vocabulary. They need objects which they can see or handle. EYL do not comprehend abstract subjects such as grammar. (Thomson, n.d.) noted that young learners don't have a concept of ideas such as parts of speech, discourse or phonology. (Cameron, n.d.) says that:

Some differences are immediately obvious: children are more enthusiastic and lively as learners. They want to please the teacher rather than peer-groups. They will have a go at an activity even when they don't quite understand why or how. However, they also lose interest more quickly and are less able to keep themselves motivated on tasks they find difficult. Children do not find it as easy to use language to talk about language; in other words, they do not have the same access as older learners to meta-language that teachers can use to explain about grammar or discourse. Children often seem embarrassed than adults at talking in a new language, and their lack inhibition seems to help them get a more native-like accent.

EYL's characteristics are necessary to be known and understood by EYL's teachers. It is done because it will influence many aspects in teaching English to EYL. The aspects are: teaching style, methods, teaching materials, lesson plan and the way of getting along with them. The aspects becomes important to be understood by EYL's teachers as EYL usually want to know about everything, as Pinter in (Terbuka \& Cabe, 2014) said that young learners have a great curiosity to try new things and to explore concrete to abstract things. Harmer in (Terbuka \& Cabe, 2014) also explains that young learners get their understanding not only from explanation but also from what they see and hear, learn when they have a chance to touch and interact with (experience it).

Juhana in (Kusumawardhani, 2006) said that teaching English as a foreign language to young learners needs special approach since young learners have special characteristics. It is stated that the improvement of abilities to learn foreign language is started from the early age. Teaching EYL needs interesting materials. It is done in order to get the EYLs' attention as EYLs' knowledge, especially about language, is limited. (Mart, 2012) said that young learners have a quite short attention span and are easy to get bored. So, comprehending the EYL's characteristics and selecting the suitable materials are important in order to be successful in teaching EYL.

Based on the theories above, it can be concluded that English learners, especially EYL can improve their writing skills through watching a movie. It can be said as EYL tends to see the pictures than read a book, a novel, a comic, etc. Educators should also select the materials which will provide the knowledge that is most applicable to their classroom as EYL have special characteristics.

\section{RESEARCH METHOD}

The participants of this research were the English Young Learners (EYL), which the age between 10-12 years old, from one of the English Courses at Gading Serpong, Tangerang. The data for this research was taken from the learners' story paper and the method used in this research is descriptive qualitative.

Descriptive method was used as (Best \& Kahn, 1995) explained that descriptive method is the method which tries to give the explanation about the symptoms relating to the recent situation. It consists on the effort of giving the note, the analysis and the interpretation of the recent symptoms which have the characteristics as follows: try to give the fact, straight to the problem and the recent variables aren't manipulated by the researcher.

Reading the story, identifying the prefixes and suffixes, classifying then analyzing them were done as the procedures of the research. They were done in order to know about the effectiveness of using story for teaching affixes to English Young Learners (EYL).

\section{FINDINGS AND RESULTS}

The steps in doing the research were asked the students to read the story, identified the affixes, classified then analyzed them. Here is the story that was used as the instrument to do the research. 


\section{Hansel and Gretel}

A poor woodcutter and his wife had two children named Hansel and Gretel. Their mother died when they were young. Hansel and Gretel were very sad. Soon their father remarried but their stepmother was very cruel. One day, she took the children deep into the forest and left them there. Clever Hansel had some breadcrumbs in his pocket and had dropped them on the way so that they could find their way back home. Alas! The birds ate all the crumbs and they couldn't find the path that led back home.

Hansel and Gretel went deeper and deeper into the forest. They were hungry and tired. Finally, after walking for a long time, they saw a cottage made of chocolate, candies, and cake. "Look, Hansel! A chocolate brick!" shouted Gretel in delight and both ate it hungrily.

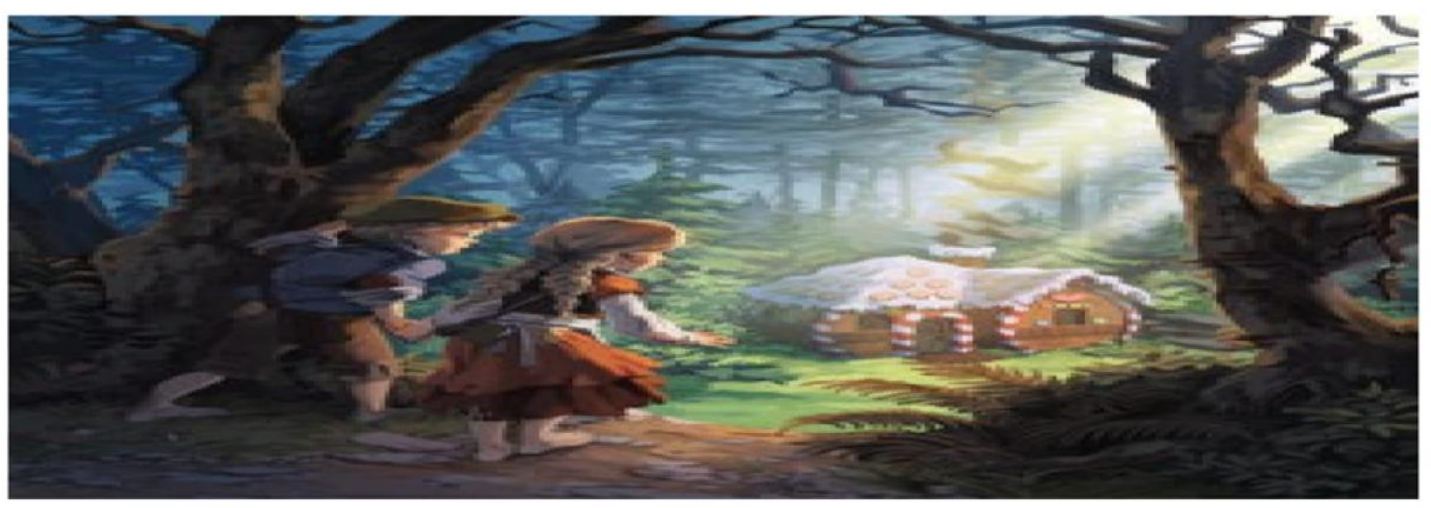

Now, a wicked witch lived there. When she saw Hansel and Gretel, she wanted to eat them. She grabbed the children and locked them in a cage. The witch decided to make a soup out of Hansel and eat him first. She began boiling a huge pot of water for the soup. Just then, Gretel crept out of her cage. She gave the wicked witch a mighty push from behind and the witch fell into the boiling water. She howled in pain and died instantly. Hansel and Gretel found treasure lying around the cottage. They carried it home with them. Their stepmother had died and their father welcomed them back with tears of joy. They never went hungry again!

http://shortstoriesshort.com/story/hansel-and-gretel/

Figure 3. Story of Hansel and Gretel

After the participants read the story, then the affixes were identified, classified and analyzed. Here are the affixes found in the story.

Table 1. PREFIX

\begin{tabular}{|l|l|}
\hline \multicolumn{1}{|c|}{ Prefix } & \multicolumn{1}{c|}{ Word } \\
\hline re- & Remarried \\
\hline step- & Stepmother \\
\hline
\end{tabular}


Table 2. SUFFIX

\begin{tabular}{|c|c|}
\hline Suffix & Word \\
\hline \multirow[t]{2}{*}{-er } & Woodcutter \\
\hline & Deeper \\
\hline \multirow[t]{15}{*}{-ed } & Named \\
\hline & Died \\
\hline & Remarried \\
\hline & Dropped \\
\hline & Tired \\
\hline & Shouted \\
\hline & Wicked \\
\hline & Lived \\
\hline & Wanted \\
\hline & Grabbed \\
\hline & Locked \\
\hline & Decided \\
\hline & Howled \\
\hline & Carried \\
\hline & Welcomed \\
\hline \multirow[t]{5}{*}{$-\mathrm{S}$} & Breadcrumbs \\
\hline & Birds \\
\hline & Crumbs \\
\hline & Candies \\
\hline & Tears \\
\hline \multirow[t]{3}{*}{$-1 y$} & Finally \\
\hline & Hungrily \\
\hline & Instantly \\
\hline \multirow[t]{2}{*}{-ing } & Walking \\
\hline & Boiling \\
\hline
\end{tabular}

Based on the findings above, there are many suffixes found in the story. Suffixes are most commonly used not only in written but also in spoken English.

There are 2 prefixes found in the story, they are re- in remarried and step- in stepmother, meanwhile there are 5 suffixes found in the story, they are -er, -ed, -s, -ly and -ing.

\section{CONCLUSION}

There are two kinds in affixations; they are derivational affixes and inflectional affixes. Most suffixes found in the story were about inflectional affixes. The suffixes found in the story are -er, -ed, $-\mathrm{s},-$ ly and -ing. There are also 2 prefixes found in the story, they are -re- and step-.

Suffix -ed are the most common suffix found in the story as the story is about retelling story then retelling story uses simple past tense so suffix -ed becomes the most common used in the story

\section{REFERENCES}

Aronoff, M., \& Fudeman, K. (n.d.). What is Morphology?

Best, J. W., \& Kahn, J. V. (1995). in Education.

Cameron, L. (n.d.). Teaching Languages to Young Learners.

Josiah, U. E., \& Udoudom, J. C. (2012).

Morphophonemic Analysis of Inflectional Morphemes in English and Ibibio Nouns: Implications for Linguistic Studies. Journal of Education and Learning, 1(2), 72-81. https://doi.org/10.5539/jel.v1n2p72

Khan, S., Akram, W., \& Khan, A. (2016).

Functions of Inflectional Morphemes in English and Pashto Languages, 3(1), 197- 
216.

Kusumawardhani, P. (2006). THE ANALYSIS OF TEACHING WRITING TO ENGLISH YOUNG LEARNERS ( EYL ) THROUGH A MOVIE : AN ICT PERSPECTIVE.

Kusumawardhani, P. (2018). the Error Analysis of Derivational Morphology in Efl ' S Engilish Narrative Composition, 2(1), 2. https://doi.org/10.26858/ijole.v2i1.4857

March, H. D., Author, T., Reserved, A. R., Development, P., Street, M., \& York, N.
(2014). English , Azerbaijani and Persian Languages : A Comparative Study, 3(1), $593-$ 614.

Mart, C. T. (2012). Encouraging Young Learners to Learn English through Stories, 5(5), 101-106. https://doi.org/10.5539/elt.v5n5p101

Terbuka, U., \& Cabe, P. (2014). Teaching English to Young Learners: Some Points to be Considered, 02(01), 43-46.

Thomson, S. (n.d.). Teaching Young Learners : Adapting the classroom for YELLs, 1-17. 